\title{
Genetic variation among the geographic population of Cassava mealybug Phenacoccus manihoti (Hemiptera: Pseudococcidae) in Indonesia inferred from mitochondrial COI gene sequence
}

\author{
NOPRIAWANSYAH ${ }^{1, \vartheta}$, AUNU RAUF ${ }^{2, v v}$, YAYI M. KUSUMAH ${ }^{2, v v}$ ALI NURMANSYAH ${ }^{2, \bullet v}$ \\ YONNY KOESMARYONO ${ }^{3, v 4}$ \\ ${ }^{1}$ Tanjung Priok Agricultural Quarantine, Agriculture Quarantine Agency, Ministry of Agriculture, Indonesia. J1. Enggano No. 17 Tanjung Priok, North \\ Jakarta 14310, Jakarta, Indonesia. Tel.: +62-21-43931549, `email: noprihamdan@ yahoo.co.id \\ ${ }^{2}$ Department of Plant Protection, Faculty of Agriculture, Institut Pertanian Bogor. J1. Meranti, Dramaga Campus, Bogor 16680, West Java, Indonesia \\ ${ }^{3}$ Department of Geophysics and Meteorology, Faculty of Mathematics and Natural Sciences, Institut Pertanian Bogor. Jl. Meranti, Dramaga Campus, \\ Bogor 16680, West Java, Indonesia
}

Manuscript received: 7 May 2019. Revision accepted: 27 August 2019.

\begin{abstract}
Nopriawansyah N, Rauf A, Kusumah YM, Nurmansyah A, Koesmaryono Y. 2019. Genetic variation among the geographic population of Cassava mealybug Phenacoccus manihoti (Hemiptera: Pseudococcidae) in Indonesia inferred from mitochondrial COI gene sequence. Biodiversitas 20: 2685-2692. Cassava mealybug, Phenacoccus manihoti Matile-Ferrero (Hemiptera: Pseudococcidae) is an invasive pest native to South America. Research was conducted with the objective to study genetic variation of cassava mealybug from different geographic areas in Indonesia. Thirty-six samples of cassava mealybugs were collected from eight different population locations. Genomic DNA was extracted from individual specimens of P. manihoti using gSYNC DNA Extraction Kit from Geneaid Lot No. FB221707. PCR amplification using primary CO1 gene showed the target position as long as 518 bp. Analysis of homology from eight populations revealed eight haplotypes in Indonesia with different variable sites. Genetic distance analysis was done by calculating base pair differences in each population. The percentage of genetic distance between populations was $0.0000 \%-0.00409 \%$. The results of the analyst using the Kimura-2 parameter showed that the population was divided into 2 clusters. The highest haplotype $(H d)$ diversity value was 0.8333 , while the lowest was zero $(H d=0)$. The highest nucleotide diversity $(\pi)$ was 0.00225 and the lowest was 0.000000 . The genetic distance and nucleotide diversity were low because P. manihoti was thelytoky parthenogenesis.
\end{abstract}

Keywords: Cassava mealybug, CO1, genetic diversity, Phenacoccus manihoti

\section{INTRODUCTION}

The cassava mealybug Phenacoccus manihoti Matile-Ferrero (Hemiptera: Pseudococcidae), is an invasive alien pest that originates from South America (Cox \& Williams 1981). It devastated cassava when inadvertently introduced to Congo in early 1970s and from there it spread to rest of the cassava growing areas in the continent of Africa, In the absence of its natural enemies, the mealybug spread rapidly across tropical Africa (Neuenschwander 2003). In South America, P. manihoti is present only in restricted areas of Paraguay, Brazil, and Bolivia (Williams \& Granara de Willink, 1992). In 2008, P. manihoti was discovered in Asia for the first time, damaging cassava in Thailand (Winotai et al, 2010). The cassava mealybugs have also been recorded in Malaysia (Sartiami et al. 2015). In Indonesia, this pest was first detected in Bogor (West Java) in 2010 (Muniappan et al. 2011). Based on the field survey in 2016-2017, P. manihoti had already been widespread in Java, Lampung, NTB and NTT (Abduchalek et al. 2017; Wyckhuys et al. 2018).

This mealybug species has been recognized as the main important pest in the world where there are cassava plantations. $P$. manihoti reproduces through thelytoky parthenogenesis, which all the offspring produced are female, hence one single mealybug can reproduce and in the abundant population, it can cause pests explosion in the plantations (Catalayud \& Ru 2006). The attack of $P$. manihoti in cassava plants generally occurs in the shoots. At a very high population density, and as it is usually the case in dry season, the attack caused the shoots to curl, book segment to shorten, and plant to become stunted (Wyckhuys et al. 2018). Since the 1970s, P. manihoti attacks on cassava plantations in Africa has caused severe damage and huge loss of yield and even raised problems of hunger for local people (Parsa et al. 2012). Severe attacks can cause about $80 \%$ loss of results as happened in Africa (Nwanze 1982) and 40-50\% in Asia (Wyckhuys et al. 2014). Therefore, $P$. manihoti can threaten cassava production and food security in affected areas (Yonow et al. 2017).

The information on the genetic aspects of the geographic variation in an insect pest can provide important biological information for deploying aphidresistant cultivars, and developing alternative chemicals for control strategies (Xu et al., 2011). The high degree of morphological similarity among different mealybug taxa is a major problem for P. manihoti control and assessment of its systematic biology or their populations. The morphological examination that is time-consuming and can 
be conducted only in the appropriate development stage (mostly on adult females) requires a high level of expertise and can not always distinguish among taxa especially with a high degree of similarity (Malausa 2011).

Molecular techniques are one way to find out the ecology and genetics of insects. DNA analysis can provide a more detailed evaluation of analysis of biotype, colonization, dispersal, diversity between species and intraspecies, insect interactions, and morphologically similar species, and is one of the most popular molecular markers used for population genetics and insect evolution (Hoy 1994). Mitochondrial DNA has an evolutionary rate of 1 to 10 times faster than nuclear DNA (Avise et al. 1987). mtDNA is widely used to study genetic variation, population genetic structure, phylogeny, and phylogenetic relationships at various taxonomic levels (Xu et al. 2011).

Mitochondrial DNA is generally used to study genetic variation, population genetic structure, phylogeny, and phylogenetic relationship at various levels of the taxonomy (Xu et al. 2011). The most widely used mitochondrial DNA is the cytochrome c oxidase subunit 1 (CO1) gene while the most widely used marker in the analysis of genetic variation is $\mathrm{mt} \mathrm{COI}$ and $\mathrm{mt} \mathrm{COII}$ (Simon et al. 2006). The CO1 gene is also used to solve-how does it solve, find the correct word to use here cryptic species, synonyms, and species extinction (Hebert et al. 2003b). Using the $\mathrm{CO} 1$ gene has been carried out to see characterization and identification of the genus Pseudococcidae (Malausa et al. 2011) and genus Lepidoptera (Palraju et al. 2018). In Thailand, the use of the CO1 mtDNA gene in the analysis of the genetic variation of $P$. manihoti has been reported and it found 7 haplotypes (Rattanawannee \& Chongrattanameteekul 2015). The COI gene is also used to test the evolutionary pace of invasive species compared to closely-related non- invasive species, and to see genetic diversity between invasive species (Young et al. 2018).

This study aimed to study the genetic variation of $P$. manihoti in Indonesia based on the analysis of markers of the mitochondrial DNA CO1 gene.

\section{MATERIALS AND METHODS}

\section{Sample collection and identification of $P$. manihoti}

A total of $36 P$. manihoti individuals were collected from 8 locations (populations), namely Bangka Island, Sumatra Island (Lampung), Java Island (Cilegon, Bogor, Semarang, Pati, Malang) and Lombok. Figure 1 Location of the sampling distribution. Samples were maintained in the laboratory before identification was carried out morphologically to ensure that the sample was $P$. manihoti. Morphological identification was conducted under the Hyrox microscope using an identification key from Williams and de Willink (1992). The identified mealybugs were then collected, soaked in $95 \%$ ethanol, and used for DNA extraction.

\section{DNA extraction}

The DNA genome was extracted from individual $P$. manihoti using the gSYNC DNA Extraction Kit from Geneaid with the extraction method by the Geneaid kit protocol. The extracted DNA was visualized through $1.2 \%$ agarose gel electrophoresis method using a 1xTAE buffer (40 mM Tris-acetate, $1 \mathrm{mM}$ EDTA) for 50 minutes. Agarose gel was then stained with ethidium bromide $(0.5 \mathrm{~g}$ $/ \mathrm{ml}$ ), observed, and documented using GEL DOC under $400 \mathrm{~nm}$ ultraviolet light.

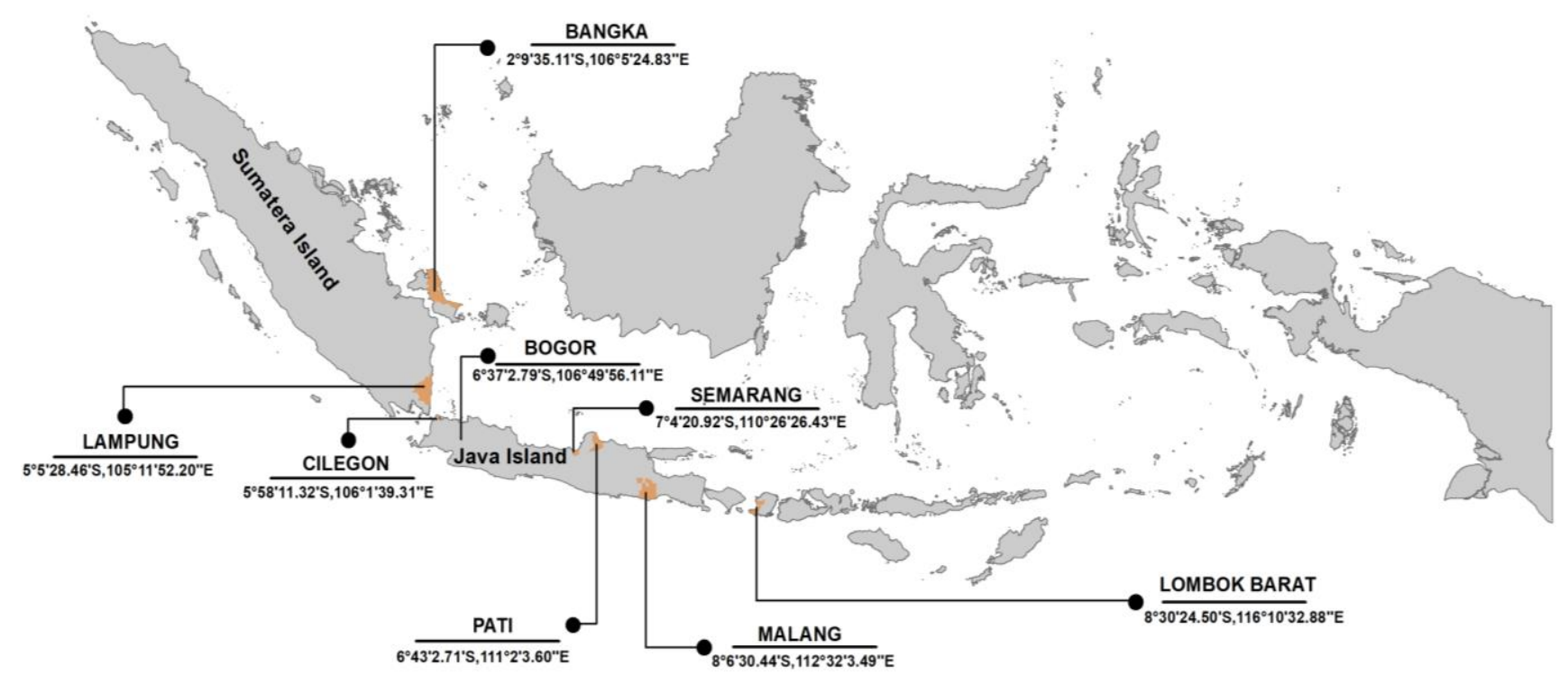

Figure 1. Map of Phenacoccus manihoti sampling location in Indonesia 


\section{Amplification and sequencing}

DNA amplification used the GeneAmp PCR System 9700 engine. The volume of reactants was $25 \mu \mathrm{L}$ which consisted of PCR-grade water $8.5 \mu \mathrm{L}$, master mix $2 \mathrm{X}$ KAPA Taq Extra HS with Dye $12.5 \mu \mathrm{L}, 1 \mu \mathrm{L}$ forward primer, $1 \mu \mathrm{L}$ reverse primer and $2 \mu \mathrm{L}$ template DNA. The pair of CO1 primers used were primer LCO1490 forward 5'ATAACTATACCTATYATTATTGGAAG'-3 and HCO 2198 reverse 5'-TAAACTTCAGGGTGACCAAAAAA TCA'3 (Rattanawannee and Chongrattanameteekul 2015). The PCR conditions used were as follows, (i) denaturation at $95^{\circ} \mathrm{C}$ for 5 minutes, (ii) annealing $48^{\circ} \mathrm{C}$ for 30 seconds, and (iii) extension of chain (synthetic DNA) at $72^{\circ} \mathrm{C}$ for 5 minutes. PCR products were detected by electrophoresis on $1.2 \%$ agarose gel using TAE-1x buffer. The PCR product which showed a single band ribbon was ended for DNA sequencing at 1st BASE, Singapore.

\section{Data analysis}

Sequencing data were aligned using the MEGA Ver.6 application (Molecular Evolutionary Genetics Analysis) (Tamura et al. 2013). Analysis of population structure was done through differences in the level of distance between populations. Arlequin application (Excoffier et al. 1992). Calculation of genetic distance and reconstruction of phylogenetic trees were based on Neighbor-joining methods employing Kimura 2-parameter method which was repeated using bootstraps 1000 times. Analysis of genetic diversity was carried out for all individuals obtained at each observation location as representation of samples at each location. This analysis used the DNA Sequence Polymorphism application as a standard measure in calculating genetic diversity which included the diversity of haplotypes $(H d)$ and nucleotide diversity $(\pi)$ (Rozas et al. 2003).

\section{RESULTS AND DISCUSSION}

\section{Morphology of Phenacoccus manihoti}

Characteristics of $P$. manihoti from the results of making slide preparations were $1.70 \mathrm{~mm}$ long and $0.90 \mathrm{~mm}$ wide, cerarii numbering 9-18 pairs, Circulus and oral rim tubular ducts entirely absent, anal lobe bars absent, antennae with 9 segments, claw denticles usually present, Multilocular disc pores on dorsum not present in rows across the segments, Quinquelocular pores anterior to clypeolabral shield numbering 32-68.

\section{Characteristics of Phenacoccus manihoti based on gen CO1}

Total DNA in P. manihoti samples were successfully isolated. The DNA band from the PCR products showed the position of the CO1 gene with a length of $518 \mathrm{bp}$ (Figure 2). BLAST of the CO1 gene sequence showed the identity of eight populations at $99 \%$ with the query cover 97\%. Multiple alignments of the CO1 gene from eight populations with a total of $36 P$. manihoti individuals showed a conservative site of $434(83622 \%)$ as the highest and the lowest was a parsimony site of $10(1.92 \%)$. The average composition of $\mathrm{A}+\mathrm{T}$ nucleotide base pairs was higher $(79.7 \%)$ than $\mathrm{G}+\mathrm{C}(20.3 \%)$ in the $\mathrm{CO} 1$ gene (Table 1).

\section{Homology analysis of mitochondrial CO1 Genes}

Analysis of the mitochondrial DNA COI gene $P$. manihoti obtained a length of 518 base pairs. Analysis of homology from eight populations found eight haplotypes in Indonesia with different variable sites. There are seven variable sites that change, i.e., in the 9th, 10th, 12th, 509th, 510th, 511th, and 512th nucleotide sequences. The highest number of individuals in the haplotype are 13 individuals in several populations, consisting of P. manihoti (Bangka1, Bangka-2, Bangka-3, Bangka-4, Bangka-5, Malang-1, Malang-2, Malang-3, Malang-4, Pati-1, Pati-2, Pati-3, Pati4). The Lampung population has three haplotypes (Table 1). This analysis shows the existence of specific nucleotide sites between $P$. manihoti populations from Indonesia with GenBank P. manihoti data from China. Specific nucleotide sites were found at the 12th position with nucleotide $\mathrm{T}$ (Timin) characteristics for Indonesia and A (Adenine) for China (Table 2).

\section{Genetic variation}

The diversity of haplotypes (Hd) between populations ranges from 0.00000 to 0.83333 . The highest haplotype (Hd) diversity value was found in Lampung population at 0.83333 while the lowest was zero $(\mathrm{Hd}=0)$ found in the populations of Bangka Island, Bogor, Malang, Pati, and Lombok. The same thing is also shown from the results of nucleotide diversity analysis $(\pi)$ where the highest value was 0.002358 in the Lampung region and the lowest was 0.0000, namely in the Bangka, Bogor, Malang, Pati and Lombok regions (Table 3).

\section{Genetic distance}

The percentage of genetic distance between $P$. manihoti populations was 0.00000-0.00409. The largest genetic distance of 0.00409 between populations occurred in the population of Bangka-Semarang, Cilegon-Semarang, Malang-Semarang, Pati-Semarang, Lombok-Semarang, while the smallest genetic distance between populations occurred between the population of Bangka-Cilegon, Bangka-Malang, Bangka-Pati, Bangka-Lombok, CilegonMalang, Cilegon-Pati, Cilegon-Lombok, Malang-Pati, Malang-Lombok, Pati-Lombok, each was 0.0000 , while the average genetic distance between populations was 0.000127 . The genetic distance between $P$. manihoti from China with samples was $0.00614-0.00204$. The genetic distance between $P$. manihoti from the whole population with $P$. madeirensis was around 0.14645 (14.645\%)-15135 $(15.135 \%)$ and $P$. parvus was around $0.03357(3.35 \%)-$ 0.14108 (14.108\%) (Tabel 4).

Based on the Fst results through the AMOVA test, the structure of population $P$. manihoti has a variation value between populations found in the entire observation population of $91.96 \%$, while value of intrapopulation variation is $8.04 \%$. The $F s t$ value for the entire population was 0.91958 ( $\mathrm{p}=0.0000)$. 
Table 1. Phenacoccus manihoti nucleotide composition

\begin{tabular}{|c|c|c|c|c|c|c|c|c|c|}
\hline \multirow{2}{*}{ Characteristics } & \multicolumn{8}{|c|}{ Population } & \multirow{2}{*}{ Average } \\
\hline & Bangka & Lampung & Bogor & Cilegon & Semarang & Malang & Pati & Lombok & \\
\hline$\overline{\operatorname{Timin}(\mathrm{T})}$ & 47.1 & 47.2 & 47.2 & 47 & 47.01 & 47.1 & 47.1 & 47.01 & 47.09 \\
\hline Sitosin $(C)$ & 13.71 & 13.56 & 13.56 & 13.61 & 13.61 & 13.71 & 13.71 & 13.61 & 13.64 \\
\hline $\operatorname{Adenosin}(\mathrm{A})$ & 32.63 & 32.48 & 32.48 & 32.63 & 32.82 & 32.63 & 32.63 & 32.63 & 32.61 \\
\hline Guanin $(\mathrm{G})$ & 6.56 & 6.76 & 6.76 & 6.76 & 6.56 & 6.56 & 6.56 & 6.76 & 6.66 \\
\hline
\end{tabular}

Table 2 Analysis of homology of the mitochondrial CO1 gene

\begin{tabular}{|c|c|c|c|c|c|c|}
\hline \multirow[b]{2}{*}{ Phenacoccus manihoti individual } & \multicolumn{5}{|c|}{ The nucleotide site } & \multirow{2}{*}{ 送 } \\
\hline & & $\begin{array}{l}1 \\
\mathbf{2}\end{array}$ & $\begin{array}{ll}5 & 5 \\
0 & 1 \\
9 & 0\end{array}$ & $\begin{array}{ll}5 & 5 \\
1 & 1 \\
0 & 1\end{array}$ & $\begin{array}{ll}5 & 5 \\
1 & 1 \\
1 & 2\end{array}$ & \\
\hline Bangka-1, Bangka-2, Bangka-3 & A C & $\mathrm{T}$ & $\mathrm{C} \mathrm{T}$ & $\mathrm{T} \mathrm{G}$ & $\overline{\mathrm{G} \mathrm{A}}$ & 1 \\
\hline Bangka-4, Bangka-5, Malang-1 & . . & 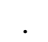 & . . & . . & . . & \\
\hline Malang-1, Malang-2, Malang-3 & . . & . & . . & . & . & \\
\hline Malang-4, Pati-1, Pati-2, Pati-3 & . . & . & . & . & . & \\
\hline Pati-4 & & . & & . & . & \\
\hline Lampung-1, Lampung-3 & $\mathrm{T}$ & . & $\mathrm{T} \mathrm{G}$ & $\mathrm{G}$ & . & 2 \\
\hline Lampung-2 & $\mathrm{T}$. & . & . G & $\mathrm{G}$ & . & 3 \\
\hline Lampung-4 & $\mathrm{T} A$ & . & $\mathrm{G}$ & $\mathrm{G}$ & . & 4 \\
\hline $\begin{array}{l}\text { Bogor-1, Bogor-2, Bogor- } 3 \text {, } \\
\text { Bogor-4, Bogor-5 }\end{array}$ & . A & & . & . & $\mathrm{C}$ & 5 \\
\hline Cilegon-1, Cilegon2 & . & & $\mathrm{T} \mathrm{G}$ & $\mathrm{G}$ & & 6 \\
\hline Cilegon-3, Cilegon-4 & & & . G & $\mathrm{G}$ & & 7 \\
\hline $\begin{array}{l}\text { Semarang-1,Semarang-2, Semarang-3 } \\
\text { Semarang-6, Semarang-6 }\end{array}$ & $\mathrm{T} A$ & & & & A & 8 \\
\hline China & & A & & & & \\
\hline
\end{tabular}

Table 3. Diversity of Phenacoccus manihoti haplotypes and nucleotides at the observation site

\begin{tabular}{lllllll}
\hline Population & $\boldsymbol{n}$ & $\boldsymbol{S}$ & $\boldsymbol{h}$ & $\boldsymbol{H d}$ & $\boldsymbol{K}$ & $\boldsymbol{\pi}$ \\
\hline Bangka & 5 & 0 & 1 & 0.00000 & 0.00000 & 0.00000 \\
Lampung & 4 & 2 & 3 & 0.83333 & 1.16667 & 0.002358 \\
Bogor & 5 & 0 & 1 & 0.00000 & 0.00000 & 0.00000 \\
Cilegon & 4 & 1 & 2 & 0.66667 & 0.66667 & 0.00000 \\
Semarang & 5 & 0 & 1 & 0.00000 & 0.00000 & 0.00000 \\
Malang & 4 & 0 & 1 & 0.00000 & 0.00000 & 0.00000 \\
Pati & 4 & 0 & 1 & 0.00000 & 0.00000 & 0.00000 \\
Lombok & 5 & 0 & 1 & 0.00000 & 0.00000 & 0.00000 \\
\hline
\end{tabular}

Note: Number of samples (n), number of polymorphic sites (S), number of haplotypes (h), diversity of haplotypes (Hd) and nucleotide diversity $(\pi)$, the average number of different $(\mathrm{K})$

\section{Phylogenetic analysis}

Analysis of kimura-2 parameter showed that the $P$. manihoti populations were divided into 2 clusters. Therefore, this study successfully proved that there was a clearly interspecific separation based on the construction of the phylogenetic tree (Figure 2). The outgroup sequence data used in this study are $P$. parvus and $P$. madeirensis, which is genetically the closest relative to $P$. manihoti. The phylogenetic reconstruction describes separate outgroups with all population samples $P$. manihoti.

\section{Discussion}

Morphological identification of imago $P$. manihoti is pink, oval in shape, soft in shape, has an antenna, body stretch is obvious and is covered with colored waxy flour, eyes are relatively prominent and the limbs develop well and are the same size. The results of making slide preparations in accordance with the key that is the body have 18 pairs of rows, antennas that have 9 segments, there are denticles on the nails, a circular shaped horn. The length of this pest is around $1.77 \mathrm{~mm}$ and $0.99 \mathrm{~mm}$ wide. Quinquelocular pores are found around the anterior head to the clypheolabral shield, reaching 32-68. Morphological observations are in accordance with the identification keys of Williams and de Willink (1992). Knowledge of this morphology is needed for the first step towards the success of research and biological control processes. According to Gardner et al. (1991) say one way to find out genetic diversity is to study phenotype differences. Morphological characters are phenotypes of external forms or real characters possessed by an individual.

This study was the first to report molecular identification of $P$. manihoti in Indonesia based on mtDNA COI genes. Understanding the characteristics of COI sequence provides better knowledge into the population's genetic structure (Liu et al. 2013). The variation in mitochondrial sequence is inherited in maternal genomes that are largely derived from gene mutations. COI is one of the mitochondrial coding and variable genes, useful in providing valuable information for the study of intraspecific polymorphisms (Barbaresi et al. 2003). Firstly found in 2010, $P$. manihoti has now spread in several regions in Indonesia. $P$. manihoti samples were found in eight locations, namely Lampung, Bangka Island, Cilegon, Bogor, Pati, Semarang, Malang, and Lombok. Characterization of base sequence of COI gene of $P$. manihoti showed a 518 bp length of the gene. The average nucleotide composition of $\mathrm{A}+\mathrm{T}$ was higher $(79.7 \%)$ than $\mathrm{G}+\mathrm{C}(20.3 \%)$ in the COI gene; Thymine (46.9\%), Adenine $(32.8 \%)$ while Cytosine $(13.6 \%)$ and Guanine $(6.6 \%)$. 
Table 4. Genetic distance between and intra Phenacoccus manihoti populations

\begin{tabular}{|c|c|c|c|c|c|c|c|c|c|c|c|}
\hline Population & Bangka & Lampung & Bogor & Cilegon & Malang & Pati & Lombok & Semarang & China & P.madeirensis & P. parvus \\
\hline Bangka & 0.00000 & & & & & & & & & & \\
\hline Lampung & 0.00255 & 0.00102 & & & & & & & & & \\
\hline Bogor & 0.00204 & 0.00357 & 0.00000 & & & & & & & & \\
\hline Cilegon & 0.00000 & 0.00255 & 0.00204 & 0.00000 & & & & & & & \\
\hline Malang & 0.00000 & 0.00255 & 0.00204 & 0.00000 & 0.00000 & & & & & & \\
\hline Pati & 0.00000 & 0.00255 & 0.00204 & 0.00000 & 0.00000 & 0.00000 & & & & & \\
\hline Lombok & 0.00000 & 0.00255 & 0.00204 & 0.00000 & 0.00000 & 0.00000 & 0.00000 & & & & \\
\hline Semarang & 0.00409 & 0.00153 & 0.00204 & 0.00409 & 0.00409 & 0.00409 & 0.00409 & 0.00000 & & & \\
\hline China & 0.00204 & 0.0046 & 0.00409 & 0.00204 & 0.00204 & 0.00204 & 0.00204 & 0.00614 & 0.00000 & & \\
\hline P.madeirensis & 0.14645 & 0.14951 & 0.1489 & 0.14645 & 0.14645 & 0.14645 & 0.14645 & 0.15135 & 0.14890 & 0.00000 & \\
\hline P. parvus & 0.03568 & 0.03834 & 0.0378 & 0.03568 & 0.03568 & 0.03568 & 0.03568 & 0.03993 & 0.03357 & 0.14108 & 0.00000 \\
\hline
\end{tabular}

This nucleotide composition value is close to that of $P$. manihoti in Thailand (Rattanawannee and Chongrattanameteekul 2015) who found thymine nucleotide composition of $47.7 \%$, cytosine of $13.7 \%$, followed by adenine of $33.1 \%$ and Guanine of $5.5 \%$. The composition of $\mathrm{A}+\mathrm{T}$ in the mitochondrial gene of insects has a tendency to have a higher number of compositions compared to the base content of G + C (Simon et al. 1994). One characteristic of mitochondrial DNA in insects is that it has a high $\mathrm{A}+\mathrm{T}$ composition (Liu and Beckenbach 1992; Simon et al. 1994). The higher composition of weak hydrogen $\mathrm{A}+\mathrm{T}$ bonds causes this gene to quickly changes as compared to other genes with higher percentage of the stronger hydrogen bonds between $\mathrm{G}+\mathrm{C}$ nucleotides.

Multiple alignments of COI genes from eight populations with total number of 36 individuals showed that there are 434 base pairs $(83,622 \%)$ of the total length of 518 base pairs nucleotides which have similarities to $P$. manihoti. Hoy (1994) mentioned some cases of thelytoky, where the egg only develops after penetration by sperm (pseudogamy or gynogenesis), but the sperm nucleus degenerates without joining the nucleus of the egg, so it provides no genetic contribution to the embryo. Than, the CO1 gene has many advantages for studying genetic characteristics because it has very little deletion and insertion in its sequence, and many parts of this gene are conserved so that it can be used as DNA barcoding in most species (Hebert et al. 2003). Besides the arrangement of amino acids from proteins encoded in the $\mathrm{CO} 1$, this gene rarely undergoes substitution, so that the $\mathrm{CO} 1$ gene is stable and can be used as a marker in phylogenetic analysis, but silent mutations are still occurring on the third bases of its codons are (Lynch and Jarrell 1993).

Genetic distance between populations is important information for studying DNA transfer from one population to another so that it can influence the microevolution of a population or species (gene flow). Freeland (2005), the factors that influence gene flow in a population are migration, limiting factors for migration, reproduction, habitat fragmentation, and metapopulation, and interspecies interactions. Based on the knowledge of genetic flow between populations through Fstatistik values, it will be known the occurrence of fragmentation or differentiation in a population. Based on the results of the FST through the AMOVA test, the population structure of $P$. manihoti has a value of the interpopulation variation of $91.96 \%$, while the value of the intrapopulation variation of $8.04 \%$. While the overall Fst value is $0.91958(\mathrm{p}=0.0000)$. The result of genetic differentiation between populations of $P$. manihoti shows that there is a genetic structure between populations. The low gene flow between populations is possible because $P$. manihoti is thelytoky parthenogenesis.

Specific nucleotide sites were found at the $12^{\text {th }}$ position with nucleotide $\mathrm{T}$ (Timin) characteristics for Indonesia and A (Adenine) for China. This shows the difference in population of $P$. manihoti from Indonesia with that from China (gene Bank data). Likewise, Rattanawannee andChongrattanameteekul (2015) stated that the results of $P$. manihoti research in Thailand obtained DNA fragments containing 419 base pairs (bp) from the COI gene. This result is different from the base length results carried out in this study amounting to 518 bp. Li (1997) stated that different nucleotide variations in the new haplotype are the result of changes in transitional and transversal substitution types. The haplotype found in this study, from all populations, had differences with the haplotypes in GenBank, so it can be concluded that the Indonesian haplotype is a new haplotype.

The results of the phylogeny tree analysis using kimura2 parameter show that the population of $P$. manihoti is divided into 2 clusters, but still shows a low bootstrap value. This indicates that $P$. manihoti in Indonesia has a very close relationship. Outgroup sequence data used in this study were $P$. parvus and $P$. madeirensis, which were genetically the closest relatives of $P$. manihoti species. The results of phylogenetic reconstruction describe separate outgroups with all $P$. manihoti population samples. This study also succeeded in showing that it was successful in proving that there was a clear interspecies separation based on phylogenetic tree construction, and also the relationship between morphological and molecular characterizations that supported each other. Research result of 
Rattanawannee dan Chongrattanameteekul (2015) who used mtCO1 DNA to identify $P$. manihoti obtained phylogenetic results into 2 clusters. Far phylogenetic differences between populations indicate significant differences in population structure (Zhao et al. 2013).
Phylogenetic trees can also be a reference to relationship based on geographical location, so that they can indicate the relationship between individuals and species through phylogenetic reconstruction (Vélez-Zuazo and Agnarsson 2011).

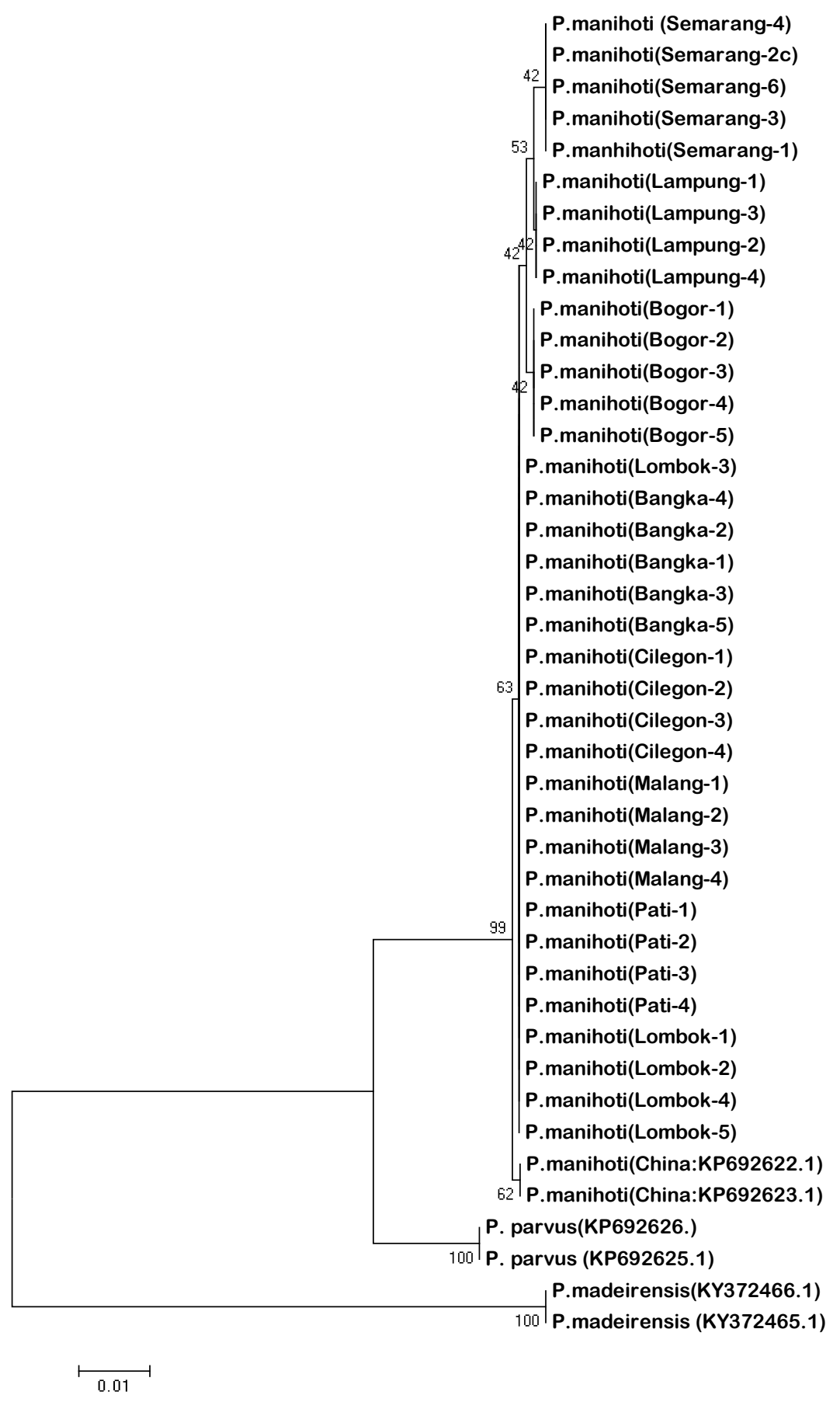

Figure 2. Phylogenetic reconstruction Phenacoccus manihoti from 8 observation populations in Indonesia using the method of Neighbor-Joining (NJ) with Kimura 2-parameter model 
Phylogenetic reconstruction of eight populations of $P$. manihoti using the Neighbor-Joining method. Outgroup sequence data used in this study are $P$. maderensis and $P$. parvus species which are genetically the closest relatives of $P$. manihoti species. Other sequential data from China were also downloaded from GenBank to be used as a comparison of data obtained from eight $P$. manihoti populations found in Indonesia. Data from the phylogenetic reconstruction represent two clusters. The first cluster consisted of all $P$. manihoti populations in Indonesia with bootstrap 42 while the second cluster of $P$. manihoti originating from China (GeneBank data) with bootstrap 63 . Whereas between $P$. manihoti populations with outgroup bootstrap values were 99. Based on two phylogenetic clusters $P$. manihoti formed, found one group with the most dominant population compared to other groups. The group consists of the population of Lombok, Bangka, Cilegon, Malang, Pati, Lombok. This is also supported by the low value of genetic distance and the presence of genetic structure between populations so that there is a suspected gene flow between populations, so the potential for phylogenetic kinship to form the same group tends to occur (Zhao 2013). The large number of populations that occur in this cluster according to Kosztarab and Kozár (1988), it is possible to spread helped by the wind, water, land, humans, and animals and wild animals. As well as their vague habits and their small size so that white lice are difficult to detect, especially if their population density in plants is low (Gullan and Martin 2003).

\section{ACKNOWLEDGEMENTS}

We thank the chief of Agricultural Quarantine Agency, Ministry of Agriculture, Republic of Indonesia and Tanjung Priok Agricultural Quarantine Office, Jakarta who helped authors in so that this research can be conducted and finally accomplished in time.

\section{REFERENCES}

Abduchalek B, Rauf A, Pudjianto. 2017: Kutu putih singkong, Phenacoccus manihoti matile-ferrero (Hemiptera: Pseudococcidae): persebaran geografi di pulau jawa dan rintisan pengendalian hayati. Jurnal Hama dan Penyakit Tumbuhan Tropika 17 (1): 1-8. [Indonesian]

Amarasekare KG, Mannion KM, Osborne LS, Epsky ND. 2008. Life history of Paracoccus marginatus (Hemiptera: Pseudococcidae) on four host plant species under laboratory conditions. Environ Entomol 37: $630-635$

Avise J, Arnold J, Ball R, Bermingham E, Lamb T, Neigel J, Reeb C, Saunders N. 1987. Intraspecific phylogeography: the mitochondrial DNA bridge between population genetics and systematics. Ann Rev Ecol Syst 18 (1): 489-522.

Barbaresi S, Fani R, Gherardi F, Mengoni A, Souty-Grosset C. 2003 Genetic variability in European populations of an invasive American crayfish: preliminary results. Biol Invasions 5 (3): 269-274.

Catalayud PA, Ru BL. 2006: Cassava-Mealybug Interactions. Institut de Reserche Pour le Development, Paris, FR.

Cox MJ, Williams DJ. 1981: An account of cassava mealybug (Hemiptera: Pseudococcidae) with a description of a new species. B. Entomol Res 71: 247-458.
Excoffier L, Smouse P, Quattro J. 1992: Analysis of molecular variance inferred from metric distances among DNA haplotypes: application to human mitochondrial DNA restriction data. Genetics 31 (2): 479-491.

Freeland J. 2005: Molecular Ecology. Wiley \& Sons, Chichester, U.K.

Gullan PJ, Martin JH. 2003. Sternorrhyncha (jumping plant-lice, whiteflies, aphids and scale insects). In: Resh VH, Cardé RT. (eds), Encyclopedia of Insects. Academic Press, Amsterdam.

Hebert P, Cywinska A, Ball SL, DeWaard JR. 2003b: Biological identifications through DNA barcodes. Proc R Soc Lond B 270: 313 321.

Hebert P, Ratnasingham S, deWaard J. 2003a: Barcoding animal life: cytochrome c oxidase subunit 1 divergence among closely related species. Proc R Soc Lond B 270 (Suppl 1): S96-99

Hoy M. 1994. Insect Molecular Genetics. Academic Press, California, USA.

Iheagwam E, Eluwa M. 1983. The effects of temperature on the development of the immature stages of the cassava mealybug, Phenacoccus manihoti Mat-Ferr. (Homoptera, Pseudococcidae). Deutsche Entomologische Zeitschrift 30 (1-3): 17-22.

Kosztarab M, Kozár F. 1988. Scale insects of central Europe. Dr. W. Junk, Dordrecht.

Lema K, Herren H. 1985. The influence of constant temperature on population growth rates of the cassava mealybug, Phenacoccus manihoti. Entomol Exp Appl 38 (2): 165-169.

Li W. 1997: Molecular evolution: Sinauer Associates Inc., Sunderland, USA.

Liu G, Zhou L, Li X, Lu D. 2013: Population genetic structure of the invasive red swamp crayfish in China revealed by ITS1 variation. Biochem Genet 51 (11-12): 841-852.

Liu H, Beckenbach A. 1992: Evolution of the mitochondrial cytochrome oxidase II gene among 10 orders of insects. Mol Phylogenet Evol 1 (1): 41-52.

Lynch M, Jarrell P. 1993. A method for calibrating molecular clocks and its application to animal mitochondrial DNA. Genetics 135 (4): 1197 1208.

Malausa T, Fenis A, Warot S, Germain J, Ris N, Prado E, Botton M, Vanlerberghe-Masutti F, Sforza R, Cruaud C. 2011. DNA markers to disentangle complexes of cryptic taxa in mealybugs (Hemiptera: Pseudococcidae). J Appl Entomol 135 (1-2): 142-155.

Muniappan R, Shepard B, Watson G, Carner G, Rauf A, Sartiami D, Hidayat P, Afun J, Goergen G, Rahman AZ. 2011: New records of invasive insects (Hemiptera: Sternorrhyncha) in Southeast Asia and West Africa. J Agric Urban Entomol 26 (4): 167-174.

Neuenschwander P. 2003. Biological control of cassava and mango mealybugs in Africa. In, P. Neuenschwander, C. Borgemeister, and J. Langewald (eds.). Biological Control in IPM Systems in Africa. CABI Publishing, Oxon, UK, pp. 55-59.

Nwanze KF, Leuschner K, Ezumah H.C. 1979: The cassava mealybug, Phenacoccus manihoti, in Republic of Zaire. PANS Intl J Pest Manag 25 (2): 125-130.

Nwanze KF. 1982. Relationship between cassava root yields and crop infestations by the mealybug, Phenacoccus manihoti. Trop Pest Manag 28: 27-32.

Palraju M, Paulchamy R, Sundaraman. 2018. Population genetic structure and molecular diversity of Leucinodes orbonalis based on mitochondrial COI gene sequences. Mitochondrial DNA 29 (8): 1231-1239.

Parsa S, Kondo T, Winotai A. 2012: The cassava mealybug (Phenacoccus manihoti) in Asia: First records, potential distribution, and an identification key. PLoS One 7 (10): e47675. DOI: 10.1371/journal.pone.0047675.

Rattanawannee A, Chongrattanameteekul W. 2015: Genetic variation of cassava mealybug, Phenacoccus manihoti (Hemiptera: Pseudococcidae), based on DNA sequences from mitochondrial and nuclear genes. Walailak J Sci Technol 13 (2): 123-132.

Rozas J, Sánchez-DelBarrio JC, Messeguer X, Rozas R. 2003. DnaSP, DNA polymorphism analyses by the coalescent and other methods. Bioinformatics 19 (18): 2496-2497.

Sartiami D, Watson GW, AB I. 2015. First record of cassava mealybug, Phenacoccus manihoti (Hemiptera: Pseudococcidae), in Malaysia. Zootaxa. 3957(2):235-238.

Simon C, Frati F, Beckenbach A, Crespi B, Liu H, Flook P. 1994: Evolution, weighting, and phylogenetic utility of mitochondrial gene sequences and a compilation of conserved polymerase chain reaction primers. Ann Entomol Soc Am 87 (6): 651-701. 
Tamura K, Stecher G, Peterson D, Filipski A, Kumar S. 2013. MEGA6: molecular evolutionary genetics analysis version 6.0. Mol Biol Evol 30 (12): 2725-2729.

Vélez-Zuazo X, Agnarsson I. 2011. Shark tales: a molecular species-level phylogeny of sharks (Selachimorpha, Chondrichthyes). Mol Phylogenet Evol 58 (2): 207-217.

Wardani N, Rauf A, Winasa W, Santoso S. 2014: Parameter neraca hayati dan pertumbuhan populasi kutu putih Phenacoccus manihoti MatileFerrero (Hemiptera: Pseudococcidae) pada dua varietas ubi kayu. Jurnal Hama dan Penyakit Tumbuhan Tropika 14 (1): 64-70. [Indonesian]

Williams D, deWillink M. 1992. Mealybugs of Central and South America. CABI, Wallingford, UK.

Winotai A, Goergen G, Tamò M, Neuenschwander P. 2010. Cassava mealybug has reached Asia. Biocontrol News Inf. 31: 10-11.

Wright S. 1943. Isolation by distance. Genetics 28: 114-138.

Wu F, Ma J, Hu X, Zeng L. 2015. Homology difference analysis of invasive mealybug species Phenacoccus solenopsis Tinsley in Southern China with COI gene sequence variability. Bull Entomol Res 105 (1): 32-39.

Wyckhuys KAG, Rauf A, Ketelaar J. 2014. Parasitoid introduced into Indonesia: Part of a region-wide campaign to tackle emerging cassava pests and diseases. Biocontrol News and Info. 35 (4): 35-37.

Wyckhuys KAG, Wongtiem P, Rauf, A, Thancharoen A, Heimpel GE, Le NTT, Fanani MZ, Gurr GM, Lundgren JG, Burra DD, Palao LK,
Hyman G, Graziosi I, Le VX, Cock MJW, Tscharntke T, Wratten SD, Nguyen LV, You M, Lu Y, Ketelaar JW, Goergen G, Neuenschwander P, Goergen G, Neuenschwander P. 2018. Continental-scale suppression of an invasive pest by a host-specific parasitoid underlines both environmental and economic benefits of arthropod biological control. PeerJ 6: e5796. DOI: $10.7717 /$ peerj.5796.

Xu Z, Chen J, Cheng D, Yong L, Frédéric F. 2011. Genetic variation among the geographic population of the grain aphid, Sitobion avenae (Hemiptera: Aphididae) in China inferred from mitochondrial COI gene sequence. Agric. Sci. China 10 (7): 1041-1048.

Yonow T, Kriticos DJ, Ota N. 2017. The potential distribution of cassava mealybug (Phenacoccus manihoti), a threat to food security for the poor. PLoS ONE 12 (3): e0173265. DOI: 10.1371/journal.pone.0173265

Young R, Mitterboeck TF, Loeza-Quintana T, Adamowicz S. 2018. Rates of molecular evolution and genetic diversity in European vs. North American populations of invasive insect species. Eur J Entomol 115: 717-728

Zhao Y, Gentekaki E, Yi Z, Lin X. 2013. Genetic differentiation of the mitochondrial cytochrome oxidase $\mathrm{c}$ subunit $\mathrm{I}$ gene in genus Paramecium (Protista, Ciliophora). PLoS One 8 (10): e77044. DOI: 10.1371/journal.pone.0077044. 